\title{
DNA Damage and Heavy Metal Content in the Mussel, Brachiodontes exustus (Linnaeus, 1758) (Mollusca: Mytilidae), from the Jobos Bay National Estuarine Research Reserve (JBERR), Salinas and Guayama, Puerto Rico ${ }^{1}$
}

\author{
Miguel P. Sastre ${ }^{2}$, Enixy Collado ${ }^{3}$, Imar Mansilla-Rivera ${ }^{4}$, and \\ Carlos J. Rodríguez-Sierra ${ }^{5}$
}

\begin{abstract}
Jobos Bay National Estuarine Research Reserve (JBNERR) is located on the southern coast of Puerto Rico. Here, the mussel Brachiodontes exustus (Mollusca: Mytilidae) is abundant on mangrove roots. DNA damage levels in B. exustus mantle cells (measured using the comet assay at $\mathrm{pH} \sim 13$ ) and metal concentrations in the remaining soft tissues (analyzed by atomic absorption spectroscopy) were measured at four sites in JBNERR. The lowest DNA damage levels were detected at the site closest to the open ocean. However, the DNA damage levels of B. exustus mantle tissue was consistently higher at the site closest to a thermoelectric power plant. These elevated damage levels could have been caused by the presence of genotoxic conditions at this site.
\end{abstract}

Key Words: DNA damage, comet assay, bioaccumulation, Brachiodontes, filter feeding, heavy metal contamination, Jobos Bay National Estuarine Research Reserve (JBNERR), Puerto Rico

Jobos Bay National Estuarine Research Reserve (JBNERR) is the second largest estuary system in Puerto Rico (Puerto Rico Department of Natural and Environmental Resources 2000, Field 2002). Important marine/estuarine habitats within JBNERR include coral reefs, seagrass beds, mangrove channels, coastal lagoons, sand beaches, mud flats and offshore keys. The area surrounding JBNERR has undergone increased industrial, agricultural and residential development that enhances the potential release of chemical pollutants into the environment. Industrial facilities near JBNERR include a 900-megawatt thermoelectric power plant, an oil refinery, pharmaceutical plants, a tire recycling center and a solid waste landfill (Puerto Rico Department of Natural and Environmental Resources 2000, Capella 2002). To effectively protect and manage this estuarine system it is important to assess the impact of chemical pollutants arising from human activities.

\footnotetext{
${ }^{1}$ Submitted on March 13, 2015. Accepted on March 31, 2015. Last revisions received on April 15, 2015.

${ }^{2}$ Corresponding author. Department of Biology, Call Box 860, University of Puerto Rico at Humacao, Humacao, Puerto Rico 00792. E-mail: miguel.sastre@ upr.edu

${ }^{3}$ Department of Biology, Call Box 860, University of Puerto Rico at Humacao, Humacao, Puerto Rico 00792.

${ }^{4}$ Graduate School of Public Health, Department of Environmental Health, University of Puerto Rico Medical Sciences Campus, San Juan, Puerto Rico 00936. E-mail: imar.mansilla@upr.edu

${ }^{5}$ Graduate School of Public Health, Department of Environmental Health, University of Puerto Rico Medical Sciences Campus, San Juan, Puerto Rico 00936. E-mail: carlos.rodriguez65@upr.edu
} 
The Scorched Mussel, Brachiodontes exustus (Linnaeus, 1758) (Mollusca: Mytilidae, Figure 1), lives mostly on the intertidal zone of bays and estuaries, attached to mangrove roots, rocks and other hard substrates, in the West Indies and the southeastern United States (Warmke and Abbott 1975, Wright and Shanks 1995). Brachiodontes exustus is an ideal bioindicator species of aquatic pollution because the mussel comes in close contact with large volumes of water during filter feeding, adapts to a wide range of environmental conditions, and because of its wide distribution in aquatic systems of Puerto Rico (Viarengo and Canesi 1991, Sastre et al. 2005). Since B. exustus is present in most of the mangrove channels within JBNERR, it could be suitable for monitoring biological effects (e.g. DNA damage), and as an indicator of heavy metal pollution.

The objectives of this study were to measure DNA damage levels in mantle cells of $B$. exustus in JBNERR using the alkaline version of the single cell gel electrophoresis, and to determine concentrations of the heavy metals, arsenic (As), cadmium $(\mathrm{Cd})$, copper $(\mathrm{Cu})$, lead $(\mathrm{Pb})$, selenium $(\mathrm{Se})$, and zinc $(\mathrm{Zn})$, in the soft tissue of mussels.

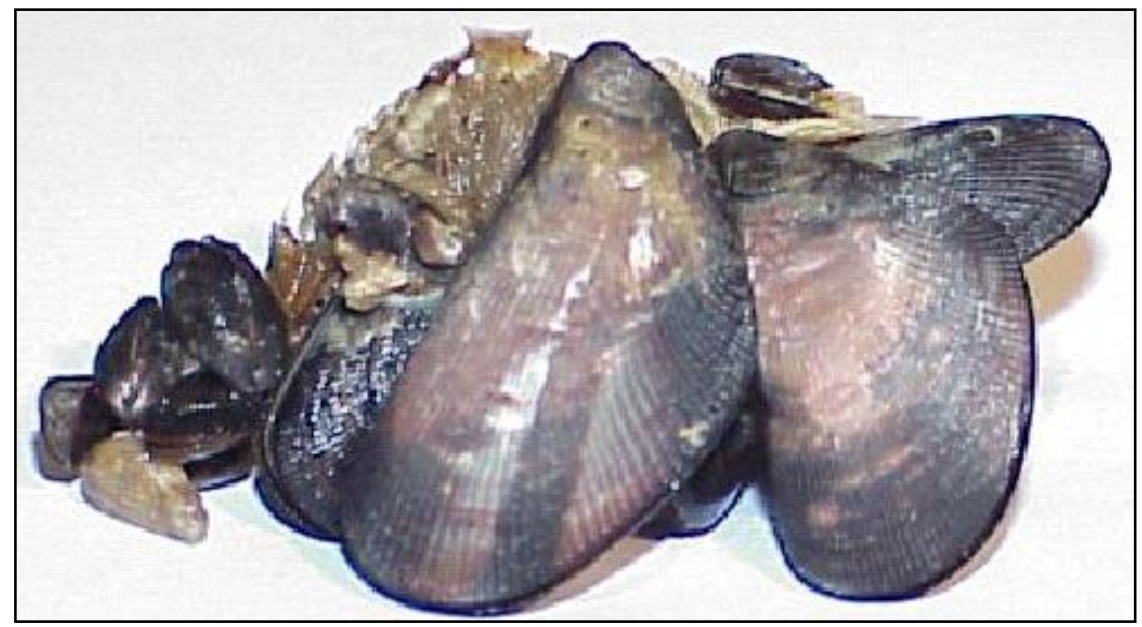

Figure 1. Cluster of Brachiodontes exustus (Linnaeus, 1758) mussels (Mollusca: Mytilidae). Approximate length of largest mussel, $3.7 \mathrm{~cm}$.

\section{Methods}

Single cell gel electrophoresis (SCGE) or comet assay detects DNA damage at the level of individual cells (Östling and Johanson 1984). The alkaline version of this technique (DNA unwinding and electrophoresis at $\mathrm{pH} \approx 13$ ) detects single and double strand breaks, alkali-labile sites, cross-links and incomplete excision repair sites. This version was developed to detect low levels of strand breaks, with high sensitivity (Singh et al. 1988). 
Four sampling sites were selected in the JBNERR (Figure 2): Las Mareas

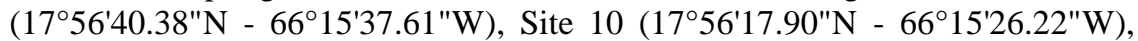
Canal $\left(17^{\circ} 56^{\prime} 12.17^{\prime \prime} \mathrm{N}-66^{\circ} 14^{\prime} 52.43^{\prime \prime} \mathrm{W}\right)$, and Site 9 (17 ${ }^{\circ} 56^{\prime} 37.16^{\prime \prime} \mathrm{N}$ $\left.66^{\circ} 14^{\prime} 18.55^{\prime \prime} \mathrm{W}\right)$. Las Mareas is located at a lagoon mostly bordered by red mangrove, Rhizophora mangle (Linnaeus, 1753) (Rhizophoraceae). A small housing development is located along the northern border of the lagoon. Houses in this community are not connected to the municipal sewer system, since these facilities are not available in this area. Therefore, untreated domestic sewage is discharged into septic tanks that can leach into the lagoon. Site 10 is located at a lagoon entirely bordered by red mangrove. The lagoon is connected to Las Mareas to the north and to the Jobos Bay to the south by means of a mangrove channel. No houses or other residential structures exist bordering the lagoon. The Canal site is located at the southernmost tip of the channel that runs from Las Mareas to Jobos Bay. It is the sampling site closest to the open ocean. Site 9 is located at the eastern boundary of JBNERR, very close to a 900-megawatt thermoelectric power plant. The bottom sediments at this site are of anthropogenic origin, composed of a black by-product of the Aguirre Sugar Mill (Field 2002), formerly located to the east of the study area.

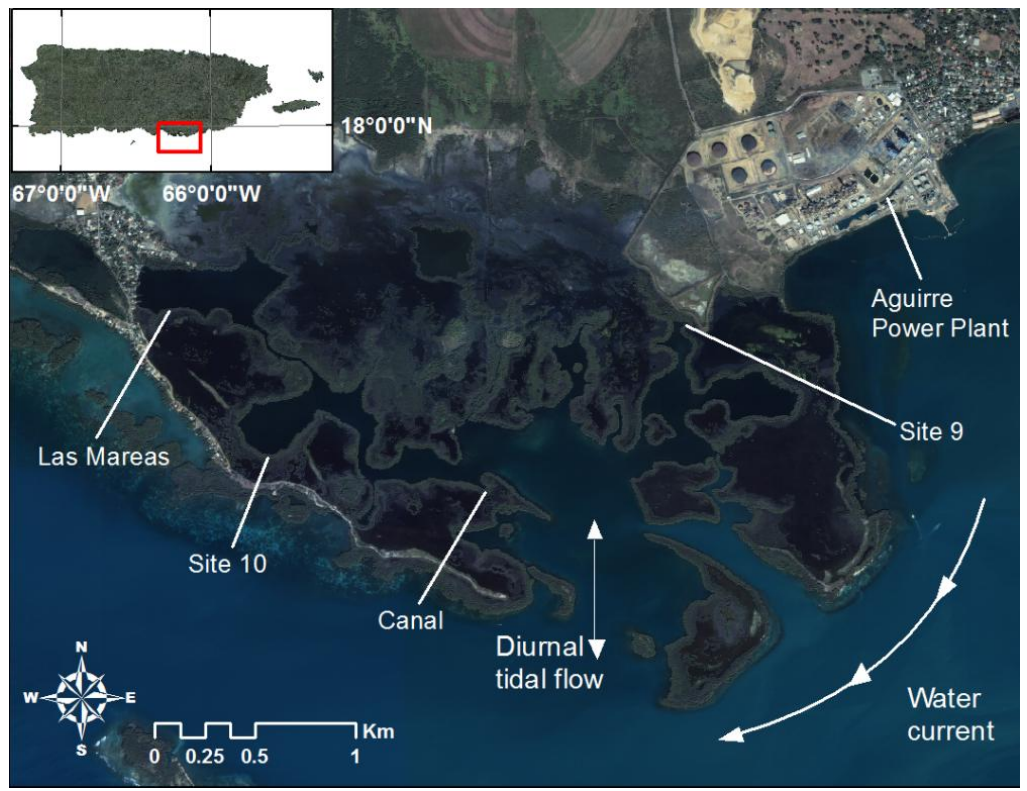

Figure 2. Satellite image of Puerto Rico (top) showing the location of the Jobos Bay National Estuarine Research Reserve (JBNERR, rectangle), in the municipalities of Salinas and Guayama, as well as a detailed image of JBNERR (bottom), showing the position of the study sites, the thermoelectric power plant, the diurnal tidal flow generalized direction, and the typical (most frequent) direction of surface currents (Capella 2002). Image from Ikonos. 
Study sites at JBNERR area were sampled on four occasions: June 27, August 21, November 6, and December 5, 2003. All B. exustus were handpicked from submerged red mangrove roots. Mussels were placed in 1-liter plastic bags containing seawater from each sampling site. The mussels in the bags were rapidly placed inside a cooler with ice (water temperature in bags approximately $2^{\circ} \mathrm{C}$ ), and transported to the laboratory within 1.5 hours. Three mussels from each sampling site at JBNERR were analyzed at each date. The total amount of mussels sampled was limited by the size and quantity of the electrophoresis chambers. Length of mussels ranged from 17-30 mm at Las Mareas, $18-31 \mathrm{~mm}$ at Site 10, 19-31 mm at Site Canal and 25-37 mm at Site 9.

Water quality data (temperature, salinity, dissolved oxygen, $\mathrm{pH}$ and turbidity) for sites 9 and 10 were provided by JBNERR's Water Quality Metadata Monitoring Program. Since this program does not acquire water quality data for the Las Mareas and Canal study sites, these were not included in Table 1. All parameters were recorded every 30 minutes using YSI model 6000 dataloggers, with probes at approximately $0.75 \mathrm{~m}$ below the mean low water level. Salinity was measured using a Fisherbrand handheld refractometer.

Mantle tissue from one valve of $\mathrm{B}$. exustus were removed with a stainless steel microdissection scissor while viewing through a Nikon Model SMZ-2T stereomicroscope, and inserted in $1.5 \mathrm{~mL}$ microcentrifuge tubes containing $900 \mu \mathrm{L}$ filtered seawater (Millipore HA type filter, $0.2 \mu \mathrm{m}$ retention size; the remaining soft tissues were used for heavy metal content analyses). One-valve mantle tissue contents were homogenized for 1 minute using a Kontes ${ }^{\circledR}$ pellet pestle motor. A $200 \mu \mathrm{L}$ aliquot was transferred into another microcentrifuge tube containing $800 \mu \mathrm{L}$ filtered seawater while kept on ice.

The alkaline version of the single cell gel electrophoresis (SCGE) or comet assay was performed according as described elsewhere (Sastre et al. 2005). Cell suspensions were spun down in a microcentrifuge at 2,000 $\times \mathrm{g}$ for 2 minutes. The supernatant was discarded and the pellet resuspended in 50-400 $\mu \mathrm{L}$ KLMA ( $0.65 \%$ FisherBiotech low melting temperature DNA grade agarose in Kenney's salt solution, consisting of $0.4 \mathrm{M} \mathrm{NaCl}, 9 \mathrm{Mm} \mathrm{KCl}, 0.7 \mathrm{Mm} \mathrm{K} 2 \mathrm{HPO} 4$, and 2 $\mathrm{Mm} \mathrm{NaHCO}, \mathrm{pH} 7.5)$ at $36^{\circ} \mathrm{C}$. The volume of KLMA depended on cell density, larger pellets were resuspended in larger volumes. Fifty (50) $\mu \mathrm{L}$ of the cell suspension was transferred on slides (duplicate slides for each mussel) previously coated with $1.0 \%$ normal melting temperature agarose (FisherBiotech, low EEO agarose) in TAE (40 Mm Tris-acetate, $1 \mathrm{Mm}$ EDTA, $\mathrm{pH}$ 7.5), allowed to gel on a stainless steel tray placed over ice, and top-coated with $50 \mu \mathrm{L}$ KLMA. Slides were placed in Coplin jars filled with lysing solution, $2.5 \mathrm{M} \mathrm{NaCl}, 10 \mathrm{Mm}$ Tris, $0.1 \mathrm{M}$ EDTA, $1 \%$ Triton X-100 and 10\% DMSO, pH 10.0 , and incubated at $4^{\circ} \mathrm{C}$ for 2 hours.

After lysis the slides were transferred to Coplin jars filled with distilled water and washed 3 times for 3 minutes in order to remove excess salts. Slides were then placed in a submarine gel electrophoresis chamber filled with alkaline 
electrophoresis buffer (300 Mm NaOH, $1 \mathrm{Mm}$ EDTA), and DNA were allowed to unwind for 15 minutes. After unwinding, electrophoresis was performed at a constant voltage of $0.4 \mathrm{~V} / \mathrm{cm}$ for 1 hour. The slides were neutralized by three 2 minute rinses in $0.4 \mathrm{M}$ Tris; and dehydrated by a 5 minute rinse in reagent alcohol (Fisher Scientific). Slides were dried at room temperature, and stained with $37 \mu \mathrm{L}$ of $1 \mu \mathrm{M}$ YOYO-1 (Molecular Probes). Duplicate slides were analyzed for each mussel.

The slides were examined under a Nikon Eclipse 600 epifluorescent microscope using a B-2A filter cube (excitation filter 450-490 nm blue light, barrier filter $520 \mathrm{~nm}$ ) at $400 \times$ magnification.

A visual scoring method was used to classify DNA damage. The scoring was not done on a blind basis but slides were selected and cells were scored haphazardly. Cells were classified into one of five categories according to tail intensity (from lowest damage, 1; to maximum damage, 5). To identify damage, images of $B$. exustus mantle cells exposed to hydrogen peroxide belonging to categories $1-5$ were printed and used as references (Sastre et al. 2005 and Figure 3). These were chosen according to damage categories observed in published photos of a similar scoring technique (Collins and Dušinská 2002, Collins 2004), but their values ranged from 0 (not damaged) to 4 (highest damaged). We decided arbitrarily to count and score at least 200 "comets" per slide. These were randomly selected and scored visually. Comets appearing as faintly stained finely fragmented DNA ("hedgehog" comets, http://www.cometassay.com/index_files/Page345.htm) not belonging to any of the classes, were not selected for the analysis.

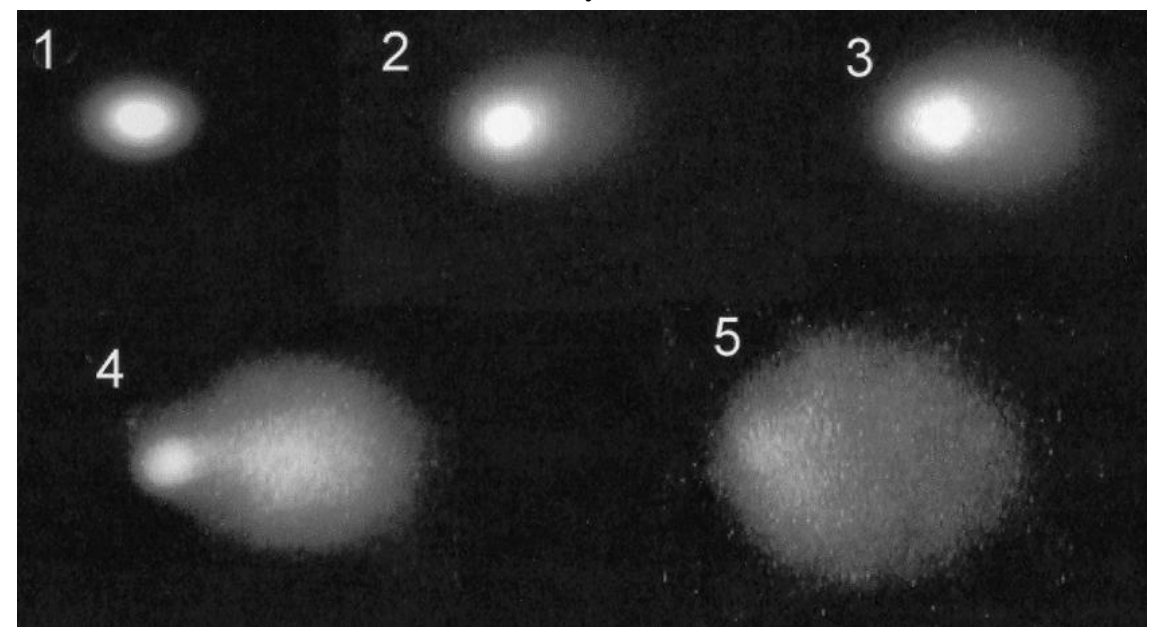

Figure 3. DNA damage classification categories used in this study. Image from Sastre et al. 2005, herein reproduced with permission of Dr. Geoffrey S. Shideler (Assistant Editor, Bulletin of Marine Science). 
A DNA damage index was calculated using a modification of the weighted average (Sokal and Rohlf 1995): DNA damage index $=\Sigma \mathrm{RN} / \Sigma \mathrm{N}$, where $\mathrm{R}=$ damage category (from 1-5); and $\mathrm{N}=$ the number of cells belonging to each damage category. The relationship between the DNA damage index of $B$. exustus and \% DNA in the tail and head has already been reported elsewhere (Sastre et al. 2005). According to Kobayashi et al., (1995), the visual scoring method can be as effective as software-based scoring. The latter was not available in our laboratory when this study was conducted.

A nonparametric Friedman Test was used to compare differences among sites (treatments) and sampling dates (blocks) (Sokal and Rohlf 1995). All pvalues $<0.05$ indicated significant deviation from the null hypothesis of no difference.

Concentrations of aesenic (As), cadmium $(\mathrm{Cd})$, copper $(\mathrm{Cu})$, lead $(\mathrm{Pb})$, selenium (Se), and zinc ( $\mathrm{Zn}$ ) were determined in the remaining soft tissue of all mussels used for DNA damage determinations. A composite sample was prepared by mixing, in separate Whirlpak ${ }^{\circledR}$ plastic bags, the soft tissue of all mussels sampled from each site $(\mathrm{n}=12$ per site). Pooling mussel samples per site was conducted because mussels were relatively small in size, thus, making it difficult to extract enough metals for the analyses. Samples were digested following USEPA Method 3051 (United States Environmental Protection Agency 1992, CEM Corporation 1994). Portions of 0.487 to $1.108 \mathrm{~g}$ wet weight, (equivalent to 0.1364 to $0.3102 \mathrm{~g}$ dry weight) were digested in a CEM sample preparation microwave oven, Model 1000 (CEM Corporation, Matthews, NC), with $10 \mathrm{~mL}$ concentrated Trace-Metal grade $\mathrm{HNO}_{3}(\mathrm{CEM}$ Corporation 1994). After digestion, samples were filtered through a Whatman 41 paper-filter, brought up to a volume of $50 \mathrm{~mL}$ with distilled deionized water, and transferred to $50 \mathrm{~mL}$ polypropylene graduated centrifuge tubes (Corning Incorporated, Corning, NY). Heavy metal analyses in the digested samples were conducted with a Perkin Elmer Atomic Absorption Spectrophotometer (AAS), Model AAnalyst 800, using modified methods of United States Environmental Protection Agency (1992) for graphite furnace and direct aspiration flame modes.

\section{Results and Discussion}

Water quality average values ( \pm 1 standard deviation) of temperature, salinity, dissolved oxygen, $\mathrm{pH}$ and turbidity, at Sites 9 and 10, from June to December 2003, are shown in Table 1. All physical-chemical parameters were similar between sites, except dissolved oxygen which was slightly higher at Site 9. Refractometer salinity determinations ranged from $30-38 \%$ at Las Mareas, from $34-37 \%$ at Site 10, from $34-35 \%$ at Canal, and from $35-37 \%$ at Site 9. 
Table 1. Average and standard deviation (in parenthesis) of monthly means of selected water quality parameters at Jobos Bay National Estuarine Research Reserve, sites 9 and 10, from June - December 2003 ( $n=7$ for all parameters).

\begin{tabular}{|c|c|c|c|c|c|c|}
\hline Site & $\begin{array}{c}\text { Temp } \\
\left({ }^{\circ} \mathbf{C}\right)\end{array}$ & $\begin{array}{c}\text { Salinity } \\
(\mathbf{\%})\end{array}$ & $\begin{array}{c}\text { Dissolved } \\
\text { Oxygen } \\
(\% \text { saturation })\end{array}$ & $\begin{array}{c}\text { Dissolved } \\
\text { Oxygen } \\
(\mathbf{m g} / \mathbf{L})\end{array}$ & $\mathbf{p H}$ & $\begin{array}{c}\text { Turbidity } \\
\text { (NTU) }\end{array}$ \\
\hline Site 9 & $\begin{array}{c}29.2 \\
(1.1)\end{array}$ & $\begin{array}{c}34.8 \\
(2.4)\end{array}$ & $54.8(10.3)$ & $3.5(0.7)$ & $\begin{array}{c}7.5 \\
(0.1)\end{array}$ & $26.9(13.3)$ \\
\hline $\begin{array}{c}\text { Site } \\
10\end{array}$ & $\begin{array}{c}29.6 \\
(1.1)\end{array}$ & $\begin{array}{c}34.5 \\
(1.9)\end{array}$ & $74.5(17.0)$ & $4.7(1.1)$ & $\begin{array}{c}7.7 \\
(0.1)\end{array}$ & $26.9(41.2)$ \\
\hline
\end{tabular}

$\mathrm{NTU}=$ nephelometric turbidity units. Data was collected every 30 minutes using a data logger.

The lowest mean DNA damage index levels were detected at the Canal site (DNA damage index $=3.12 \pm 0.67$ Standard Deviations, SD; Figure 2). In three (August 21, November 6 and December 5) out of five occasions, the DNA damage index at Canal was the lowest. Intermediate DNA damage levels were observed at Las Mareas (DNA damage index $=3.36 \pm 0.90$ SD) and Site 10 (DNA damage index $=3.43 \pm 0.84 \mathrm{SD}$, Figure 4). The mean DNA damage index of B. exustus mantle tissue was higher at Site 9 (DNA damage index $=3.89 \pm$ $0.35 \mathrm{SD}$, Figure 4), and consistently higher at this site during all sampling dates. This is reflected in a statistically significant Friedman Test $\left(\mathrm{X}^{2}\right.$ corrected for ties $=7.923$; degrees of freedom $=3$; probability $=0.0476$ ) indicating significant regularity among sites in the DNA damage index levels. At site 9 the mean DNA damage index level was the highest, and the standard error of the mean was the lowest (Figure 4).

The concentrations of $\mathrm{As}, \mathrm{Se}, \mathrm{Pb}, \mathrm{Cd}, \mathrm{Cu}$ and $\mathrm{Zn}$ in the soft tissue of $B$. exustus are shown in Table 2. The pattern of mean metal concentrations across sites is: $\mathrm{Zn}($ mean $=56.2 \pm 5.9 \mathrm{SD})>\mathrm{Cu}($ mean $=14.3 \pm 5.5 \mathrm{SD})>\mathrm{As}($ mean $=$ $12.5 \pm 2.0 \mathrm{SD})>\mathrm{Se}($ mean $=2.2 \pm 0.6 \mathrm{SD})>\mathrm{Pb}($ mean $=0.6 \pm 0.1 \mathrm{SD})>\mathrm{Cd}$ (mean $=0.11 \pm 0.02 \mathrm{SD})$.

The Canal site lies at the outermost end of the channel that runs into Las Mareas. Contaminants that caused higher DNA damage index levels in $B$. exustus at other sites should be more diluted with seawater at the Canal site. This could explain the observed lower DNA damage index levels at Canal (Figure 4). Even though Canal had higher levels of $\mathrm{Zn}$, Se and As than Site 9, higher $\mathrm{Pb}$ than Site 10, and higher $\mathrm{Cd}$ and $\mathrm{Cu}$ than Las Mareas, DNA damage index levels detected by the comet assay could be caused by a wide array of genotoxic chemicals, not necessarily the metals analyzed in this study. Naturally occurring elements can cause DNA damage or protect from DNA damage. 
Selenium in water enhances antioxidant defenses (possibly by the induction of glutathione and selenium-dependent glutathione peroxidase) and protects against copper-induced DNA damage in the blue mussel Mytilus edulis (Trevisan et al. 2011).

Las Mareas is the only sampling site where a housing community is found within a close distance. Septic tank effluents containing fecal contaminants mostly cause the anthropogenic impact at Las Mareas (Sastre 2005). Pollutants such as urine, household chemicals and drugs should be of concern. However, urine and fecal contamination is not typically associated with DNA damage.

Table 2. Metal concentrations ( $\mu \mathrm{g} / \mathrm{g}$, dry weight) in composite homogenate Brachiodontes exustus soft tissue samples from Jobos Bay National Estuarine Research Reserve. Variability statistics at each site cannot be calculated since all tissue samples were pooled.

\begin{tabular}{|l|c|c|c|c|c|c|}
\hline \multicolumn{1}{|c|}{ Site } & $\begin{array}{c}\text { As - } \\
\text { arsenic }\end{array}$ & $\begin{array}{c}\text { Se - } \\
\text { selenium }\end{array}$ & $\begin{array}{c}\text { Pb - } \\
\text { lead }\end{array}$ & $\begin{array}{c}\text { Cd - } \\
\text { cadmium }\end{array}$ & $\begin{array}{c}\text { Cu - } \\
\text { copper }\end{array}$ & $\begin{array}{c}\text { Zn - } \\
\text { zinc }\end{array}$ \\
\hline $\begin{array}{l}\text { Las } \\
\text { Mareas }\end{array}$ & 11.91 & 2.24 & 0.67 & 0.08 & 8.30 & 64.87 \\
\hline Site 10 & 10.39 & 1.33 & 0.43 & 0.12 & 11.63 & 54.29 \\
\hline Canal & 15.18 & 2.86 & 0.59 & 0.11 & 16.30 & 53.99 \\
\hline Site 9 & 12.30 & 2.22 & 0.66 & 0.12 & 20.95 & 51.57 \\
\hline & & & & & & \\
\hline mean & 12.45 & 2.16 & 0.59 & 0.11 & 14.29 & 56.18 \\
\hline SD & 2.00 & 0.63 & 0.11 & 0.02 & 5.52 & 5.92 \\
\hline CV & 0.16 & 0.29 & 0.19 & 0.16 & 0.39 & 0.11 \\
\hline
\end{tabular}

$\mathrm{SD}=$ standard deviation, $\mathrm{CV}=$ coefficient of variation .

During 1990, approximately $160,557 \mathrm{~m}^{3}$ of sediment were dredged from the thermoelectric plant pier area and main ship channel, and disposed in an area located to the north of Site 9 (Angel Dieppa, JBNERR Research Coordinator, written communication). Genotoxic chemicals in the water that may have leached from the sediment-disposal area could have caused the elevated DNA damage levels in B. exustus observed at this site. It is likely that this sediment was contaminated with fuel and other PAHs (polycyclic aromatic hydrocarbons) associated with the fuel barge traffic. Aldarondo et al. (2010) reported concentrations of $649 \mathrm{ng} / \mathrm{g}$ dry weight $\Sigma \mathrm{PAHs}$ in sediments collected from Site 9, after correcting for pyrene d-10. According to Whitall et al. (2011a) Site 9 (or nearby area) is among the stations in JBNERR having higher concentrations of total PAHs, PCBs and DDT in their sediments. It has been demonstrated that PAHs-contaminated sediments, originating from shipping activities, are linked to DNA damage in the filter feeder, Mytilus edulis L., the common or blue mussel (Steinert et al. 1998a, 1998b). Unfortunately, when this study was 
performed, we did not have the necessary means to analyze PAHs or other contaminants besides the metals analyzed in this study.

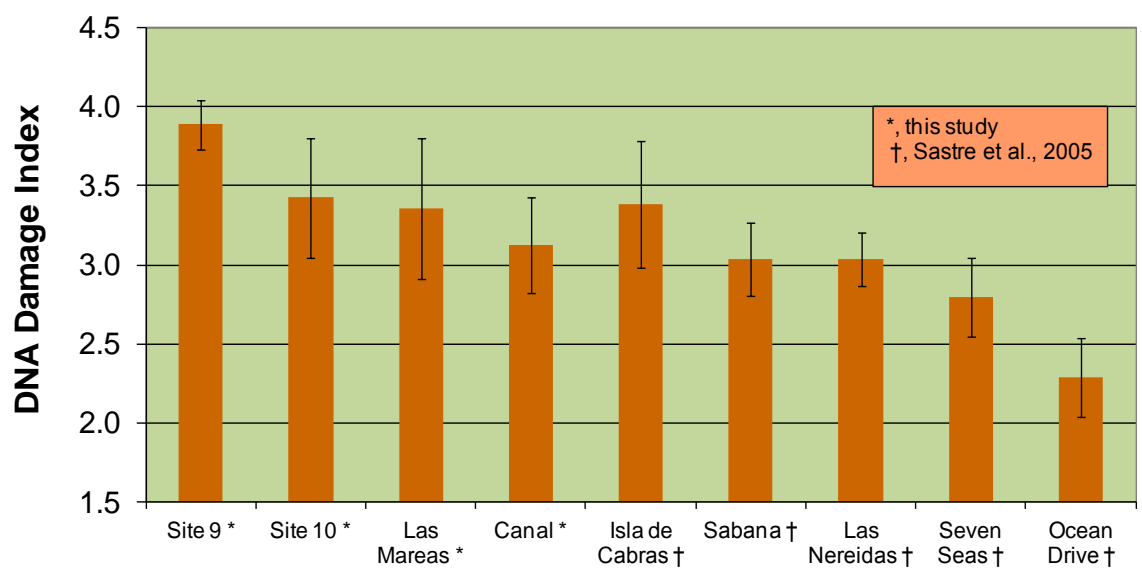

\section{Sampling Site}

Figure 4. Grand mean ( \pm 1 standard error) DNA damage index levels of the mean damage detected during each of the four sampling dates at Site 9, Site 10, Las Mareas and Canal (this study, $\mathrm{n}=3$ mussels per date); and in other Puerto Rico sites (Isla de Cabras, $\mathrm{n}=$ 8; Sabana, $\mathrm{n}=11$; Las Nereidas, $\mathrm{n}=11$; Seven Seas, $\mathrm{n}=7$; Ocean Drive, $\mathrm{n}=11$; Sastre et al. 2005); in Brachiodontes exustus mantle tissue.

The highest concentrations of the pesticide atrazine and atrazine degradates were detected in the water column after a rain event at site 9, among five stations in JBNERR, including site 10 and Las Mareas (equivalent to station 11 in Whitall et al. 2011b). Atrazine can cause DNA damage in neotropical fish species (Santos and Martinez 2012), and may have contributed to high DNA damage levels in B. exustus.

Mussels at Site 9 also obtained the highest concentrations of $\mathrm{Cu}$ in their mantle tissue (Table 2). Copper does not cause direct damage in DNA but aids the formation of oxygen radicals, which cause single strand breaks and attack on DNA bases (Bernstein and Bernstein 1991). Even though the different study sites are associated with greater or lesser amounts of genotoxic chemicals, we do not ascribe DNA damage levels in B. exustus at each site to any particular chemical because of the tremendously confounded set of factors present at JBNERR. The comet assay is capable of measuring DNA damage levels in cells but is not capable of detecting the cause of the damage, which could be confusing.

We did not find other studies reporting the bioaccumulation of these six metals in B. exustus. However, we compared our results with those measured in the false mussel, Mytilopsis domingensis Récluz another common filter feeder 
tropical bivalve that thrive in northern Puerto Rico estuaries (Pérez et al. 2001). The only metal that was consistently higher in B. exustus from JBNERR was As. The concentration of As in B. exustus from JBNERR ranged from 10.39 - 15.18 $\mu \mathrm{g} / \mathrm{g} \mathrm{dw}$, while in $M$. domingensis ranged from $1.78-3.63 \mu \mathrm{g} / \mathrm{g} \mathrm{dw}$. Zinc and Cd obtained concentrations up to $64.87 \mu \mathrm{g} / \mathrm{g} \mathrm{dw}$ (Las Mareas site) and $0.12 \mu \mathrm{g} / \mathrm{g}$ dw (Sites 9 and 10), respectively, in B. exustus from JBNERR; in comparison to M. domingensis from San José Lagoon (Puerto Rico), with the highest value being $86.3 \mu \mathrm{g} / \mathrm{g} \mathrm{dw}$ for $\mathrm{Zn}$ and $0.24 \mu \mathrm{g} / \mathrm{g} \mathrm{dw}$ for $\mathrm{Cd}$. B. exustus from Canal and Site 9 had concentrations of $\mathrm{Cu}(16.30$ and $20.95 \mu \mathrm{g} / \mathrm{g} \mathrm{dw}$, respectively) that were above the highest value obtained $(13.9 \mu \mathrm{g} / \mathrm{g} \mathrm{dw})$ by $M$. domingensis from San José Lagoon. The other metal concentrations in B. exustus were within the range obtained in $M$. domingensis from San José Lagoon and Piñones Lagoon located in the Greater San Juan Metropolitan Area, Puerto Rico.

In comparison to $M$. domingensis (Pérez et al. 2001), the pattern of mean metal concentrations in B. exustus from JBNERR only differed in As concentrations, being higher than $\mathrm{Se}$ in B. exustus. This is the first study at JBNERR in which $B$. exustus has been used as a sentinel organism to determine the effect of genotoxic chemicals by looking at DNA damage in mantle cells. In order to have a broader perspective, and more accurate and precise data, future studies should sample at all seasons, at least during one year; have a greater sample size; more sampling stations; and analyze a greater variety of genotoxic contaminants.

\section{Acknowledgments}

We would like to acknowledge the following persons who helped in various aspects of this project: Carmen González, Iris Tirado, Claudio Burgos, Ángel Dieppa, and Luis Encarnación (JBNERR); Emarie Ayala, Shirley Morales, Efraín Sánchez, Julianna Rodríguez, Rufo Vega, and Héctor Ramos (UPR-Humacao). Ricardo Colón (San Juan Bay Estuary Program, San Juan, Puerto Rico; and JBNERR) and Juan A. Pérez (Yagüez Research, LLC, Springfield, Virginia) provided satellite images, and R. Colón helped in the elaboration of Figure 2. Geoffrey S. Shideler (Assistant Editor, Bulletin of Marine Science) allowed the reproduction of Figure 3 in this article. This research was supported by NSF grant \# 0099679, Sea Grant R-91-1-03 and University of Puerto Rico Research Funds (FOPI).

\section{Literature Cited}

Abacus Concepts. 1996. Stat View Reference. Abacus Concepts. Berkeley, California. USA. 452 pp. Aldarondo-Torres, J. X., F. Samara, I. Mansilla-Rivera, D. S. Aga, and C. J. Rodríguez-Sierra. 2010. Trace Metals PAHs and PCBs in sediments from Jobos Bay area in Puerto Rico. Marine Pollution Bulletin 60:1350-1358. http://dx.doi.org/10.1016/j.marpolbul.2010.06.006

Bernstein, C. and H. Bernstein. 1991. Aging, Sex and DNA Repair. Academic Press. Salt Lake City, Utah, USA, USA. 382 pp. http://dx.doi.org/10.1016/B978-0-12-092860-6.50006-5

Capella, J. 2002. Environmental Setting. pp. 15-40. In, R. Field (Editor). Jobos Bay Estuarine Profile: a National Estuarine Research Reserve. U.S. Department of Commerce, National Oceanic and Atmospheric Administration, National Estuarine Research Reserve System. Silver Spring, Maryland, USA. 109 pp.

CEM Corporation. 1994. Microwave Digestion Application Manual. CEM Corporation. Matthews, North Carolina, USA. 265 pp.

Collins A. R. 2004. The comet assay for DNA damage and repair: principles, applications and limitations. Molecular Biotechnology 26:249-261. http://dx.doi.org/10.1385/MB:26:3:249 
Collins, A. R. and M. Dušinská. 2002. Oxidative stress biomarkers and antioxidant protocols. pp. 147-159. In, D. Armstrong (Editor). Methods in Molecular Biology 186. Humana Press. Totowa, New Jersey, USA. 322 pp.

Field, R. M. 2002. Introduction and Summary. pp 1-13. In, Field, R. and P. O. Robles (Editor). Jobos Bay Estuarine Profile: a National Estuarine Research Reserve, Aguirre, Puerto Rico. U.S. Department of Commerce, National Oceanic and Atmospheric Administration, National Ocean Service, Office of Ocean and Coastal Resource Management, Estuarine Reserve Division. Silver Spring, Maryland, USA. 109 pp.

Kobayashi, H., C. Sugiyama, Y. Morikawa, M. Hayashi, and T. Sofuni. 1995. A comparison between manual microscopic analysis and computerized image analysis in the single cell gel electrophoresis assay. MMS Communications (Japan) 3:103-115.

Laboy, E. N. 2002. Biological Setting. pp. 41-56. In, R. Field (Editor). Jobos Bay Estuarine Profile: a National Estuarine Research Reserve. U.S. Department of Commerce, National Oceanic and Atmospheric Administration, National Estuarine Research Reserve System. Silver Spring, Maryland, USA. 109 pp.

Östling, O. and K. J. Johanson. 1984. Microelectrophoretic study of radiation-induced DNA damage in individual mammalian cells. Biochemical and Biophysical Research Communications 123:291-298. http://dx.doi.org/10.1016/0006-291X(84)90411-X

Pérez, U. J., B. Jiménez, W. Delgado, and C. J. Rodríguez-Sierra. 2001. Heavy metals in the false mussel, Mytilopsis domingensis, from two tropical estuarine lagoons. Bulletin of Environmental Contamination and Toxicology 66:206-213. http://dx.doi.org/10.1007/s001280000226

Puerto Rico Department of Natural and Environmental Resources. 2000. Management Plan for the Jobos Bay National Estuarine Research Reserve. Department of Natural and Environmental Resources, and National Oceanic and Atmospheric Administration Technical Report. San Juan, Puerto Rico. 226 pp.

Santos, T. G. and C. B. R. Martinez. 2012. Atrazine promotes biochemical changes and DNA damage in a Neotropical fish species. Chemosphere 89:1118-1125. http://dx.doi.org/10.1016/j.chemosphere.2012.05.096

Sastre, M. P. 2005. Inventory of septic tanks as a source of pollution in ground water at Jobos Bay National Estuarine Research Reserve (JBNERR): determinations of fecal coliform and enterococci bacteria in oyster tissue and seawater. Technical Report, Puerto Rico Department of Natural and Environmental Resources. San Juan, Puerto Rico. 19 pp. Unpublished manuscript.

Sastre, M. P., E. Collado, G. Collazo, L. Mena, S. Morales, S. Lebrón, R. Muller, L. Pérez, P. Rivera, and Y. Vélez. 2005. DNA damage in the Caribbean mussel Brachiodontes exustus: a comet assay evaluation. Bulletin of Marine Science 77:73-82.

Singh, N. P., M. T. McCoy, R. R. Tice, and E. L. Schneider. 1988. A simple technique for quantitation of low levels of DNA damage in individual cells. Experimental Cell Research 175:184-191. http://dx.doi.org/10.1016/0014-4827(88)90265-0

Sokal, R. R. and F. J. Rohlf. 1995. Biometry. W. H. Freeman, New York, NY, USA. 887 pp.

Steinert, S. A., R. Streib-Montee, J. M. Leather, and D. B. Chadwick. 1998a. DNA damage in mussels at sites in San Diego Bay. Mutation Research 399:65-85. http://dx.doi.org/10.1016/S0027-5107(97)00267-4

Steinert, S. A., R. Streib-Montee, and M. P. Sastre. 1998b. Influence of sunlight on DNA damage in mussels exposed to polycyclic aromatic hydrocarbons. Marine and Environmental Research 46:355-358. http://dx.doi.org/10.1016/S0141-1136(97)00088-3

Trevisan, R., D. Ferraz Mello, A. S. Fisher, P. Schuwerack, A. Luiz Dafre and A. J. Moody. 2011. Selenium in water enhances antioxidant defenses and protects against copper-induced DNA damage in the blue mussel Mytilus edulis. Aquatic Toxicology 101:64-71. http:// http://dx.doi.org/10.1016/j.aquatox.2010.09.003

United States Environmental Protection Agency. 1992. Test Methods for Evaluating Solid Waste, Physical/Chemical Methods. USEPA Technical Report SW-846. Third Edition. National 
Technical Information Service, US Department of Commerce. Springfield, Virginia, USA. $3,500 \mathrm{pp}$.

Viarengo, A. and L. Canesi. 1991. Mussels as biological indicators of pollution. Aquaculture 94:225-243. http://dx.doi.org/10.1016/0044-8486(91)90120-V

Warmke, G. L. and R. T. Abbott. 1975. Caribbean Seashells. Dover Publications, Inc. New York, NY, USA. $348 \mathrm{pp}$.

Webb, R. M. T. and F. Gómez-Gómez. 1998. Synoptic survey of water quality and bottom sediments, San Juan Bay estuary system, Puerto Rico, December 1994 - July 1995. USA Geological Survey Water-Resources Investigations Report 97-4144. US Geological Survey. Reston, Virginia, USA. 69 pp.

Whitall, D. R., A. S. Pait, D. Apeti, A. Dieppa, S. E. Newton, L. Brune, C. Caldow, A. L. Mason, and J. Christensen. 2011a. Contaminants in sediments and coral tissues in Jobos Bay. pp. 111149. In, D. R. Whitall, B. M. Costa, L. J. Bauer, A. Dieppa, and S. D. Hile (Editors). A Baseline Assessment of the Ecological Resources of Jobos Bay, Puerto Rico. NOAA technical memorandum NOS NCCOS 133. Silver Spring, Maryland, USA. 188 pp.

Whitall D, A. Dieppa, and T. Potter. 2011b. Spatial and temporal variability in the water column nutrients and pesticides in Jobos Bay. pp. 151-164. In, D. R. Whitall, B. M. Costa, L. J. Bauer, A. Dieppa, and S. D. Hile (Editors). A Baseline Assessment of the Ecological Resources of Jobos Bay, Puerto Rico. NOAA technical memorandum NOS NCCOS 133. Silver Spring, Maryland, USA. 188 pp.

Wright, G. W. and A. L. Shanks. 1995. Interspecific association between bail-out behavior and habitat is geographically and phylogenetically widespread. Journal of Experimental Marine Biology and Ecology 188:133-143. http://dx.doi.org/10.1016/0022-0981(94)00196-K 